\title{
Relationship between Leadership, Motivation, and Public Services
}

\author{
Tati Hartati \\ Lecturer at Public Administration, Majalengka University, Indonesia \\ htati58@yahoo.com
}

\begin{abstract}
Public administration has a strategic value for administrators of government, development, and service to the community so that the need for effective, coordinated and sustainable public administration services. To achieve these objectives, a good motivation is needed from subdistrict head as the leader. The public administration service is apparently still not optimal. It happens because by the implementation of motivation has not been done optimally, based on the principles of motivation. This study used descriptive quantitative research methods with scoring techniques. The data collected was the primary data through questionnaire techniques and the secondary data through documentation and other supporting data. In this study, the samples were all employees in Argapura, Majalengka. The obtained results explained that the implementation of motivation by the sub-district head of Argapura based on the principles of motivation only reached the results of $61.5 \%$ which "Good Enough". Meanwhile, the effectiveness of public administration services obtained as much as 59\% in which it only achieved "Good Enough". Thus, the motivation achieving a good enough predicate will influence the effectiveness of public administration services also achieving good enough results as well.
\end{abstract}

Keywords: Leadership; motivation; service effectiveness.

\section{Introduction}

In human life, there will be a life cycle. These life cycles and important events include birth, marriage, divorce, death, and various other important events. These important events need to be recorded because they greatly affect the life experience of every human being. Considering the importance of these events and for the sake of creating an orderly and regularly state of society as well as for the sake of ensuring legal certainty, a regulation is needed to regulate them. The intended regulation is a regulation in the field of public called the Public Administration. Public Administration includes public events and important events. What is meant by public events include changes in address, moving out/moving in to settle, temporary residence, and changes the status of foreigners from temporary residence to permanent residence. Meanwhile, what is meant by important events include birth, stillbirth, death, marriage, divorce, etc. Those must be reported and need to be registered because those have implications for changing data on identity or public certificates. Thus, every public and important event requires valid evidence for administration and recording in accordance with the provisions of the Regulations.

Public administration has a strategic value for government administrators, and services to the community so that there is a need for effective, coordinated and sustainable public administration services, which will have a positive impact on public organizations. Effective service reflects that the organization has reliable performance (Hadiyati 2014; Hsiao and Lin 2008; Ramseook-munhurrun, Lukea-bhiwajee, and Naidoo 2010). To achieve this, leaderships having a high commitment in providing motivation to his subordinates to achieve expected work are needed. The results of previous researches have proven that leaders' motivation for their subordinates can have a positive impact on their employees (Hersona, Sonny. 2017; Naile and Selesho 2014; Siwi, Marheni Dharyadi, Siswandari 2019). This 
motivation is done by giving encouragement to subordinates so that the subordinates can work sincerely, and they will give all the abilities they have with enthusiasm. From this motivation, subordinates (employees) can carry out the work to the maximum, in which, ultimately, public administration services are also effective.

At sub-district office of Argapura, Majalengka, the effectiveness of public administration services is still not optimal (still low). Therefore, the sub-district head must strive to implement the motivation by encouraging his subordinates to be enthusiastic and to be able to increase their ability to carry out their work maximally, thereby it generates community's satisfaction toward the services provided. In addition, it turns out that the subdistrict head has not optimally implemented the principles of motivation maximally. In connection with the description above, the writer is very interested in conducting research on the implementation of motivation by the sub-district head in improving the effectiveness of public administration services at sub-district office of Argapura, Majalengka.

\section{Review of Literature}

\subsection{Motivation}

Motivation plays an important role in achieving the organizational goals. It is because motivation is an impulse that moves a person to do a job/work maximally to achieve the organizational goals. This impulse arises due to internal and external factors which can be in the form of stimuli or incentives. Motivation is the whole process of giving encouragement to subordinates to work so that they want to work with sincerity and the achievement of the efficient and economical organizational goals is achieved (Sondang Siagian 2012). Whereas, (Hasibuan 2016) provides an understanding that "Motivation is the provision of excitement or passion to work for employees, so that they work with all their power and efforts.

Based on some of opinions above, it can be concluded that motivation is a direction, impulse or passion to employees to be able to work in accordance with the expected goals, for the achievement of effective and efficient organizational goals. The indicators in motivation that refer to Hasibuan's opinion consist of the principle of participation, the principle of communication, the principle of recognition, the principle of delegated authority, and the principle of mutual attention.

\subsection{Effectiveness}

Effectiveness is usually interpreted as the success achieved by an organization in its efforts to achieve predetermined goals. As opinion of (Edwards 1996), effectiveness is "the achievement of goals set by cooperative effort". Clearly, if the target or goal has been achieved as it is planned before, it is called effective. Thus, if the target or goal is not completed within the allotted time, the work is not effective. Meanwhile, according to (Sugandha 1991), effectiveness is a successful work to achieve predetermined goals, because the word "effective" is a state of success in achieving targets or goals that are really useful.

From the description above, it can be concluded that effectiveness is a measurement of the success of the implementation of work in achieving the predetermined targets and goals. Effectiveness is not only seen from the results but also from the process. In addition, in achieving the effectiveness of organizational goals, it requires the implementation of indicators of effectiveness well so that organizational goals can be achieved. According to 
Gibson (Gibson, James L. 2006), the indicators of effectiveness consist of production, quality, efficiency, flexibility and satisfaction.

\subsection{Public administration}

Public administration is a very important role in development, in which the public administration system can be known about public data and public residence. Definition of public administration in article 1 paragraph (1) of Regulation No. 23 of 2006 concerning Public Administration, which is as follows:

Public administration is a series of structuring and controlling activities in the issuance of public documents and data through public registration, civil registration, management of public administration information, and utilization of the results for public services as well as development of other sectors. (Article 1 paragraph (1) of Law No. 23 of 2006)

Public administration is as a system in the administration of State Administration. In terms of public interests, public administration provides for the fulfillment of administrative rights. In carrying out public administration affairs, the government has an important role and has obligation to carry out public administration matters. The government has the obligation and responsibility to carry out public administration nationally at the Central, Provincial, District/City level. In the implementation of public administration affairs at the District/City level, it is carried out by implementing agencies. Article 27 paragraph (1) Government Regulation No. 37 of 2007 concerning the implementation of Regulation No. 23 of 2006 concerning public administration, it emphasizes that in carrying out the public administration affairs in the District/City. The department of public and civil registration was established as an implementing agency regulated in a Regional Regulation. Implementing agency is the responsible and authorized regional apparatus to carry out services in public administration matters. In carrying out its duties and functions, the implementing agency is assisted by the = sub-district, urban village, and head of neighbourhood/hamlet (RT/RW). In public administration services, it needs to be done correctly and quickly so that residents feel that they can get satisfactory services. As an extension of the village that spearheaded in terms of public administration submitted to neighbourhood/hamlet (RT/RW) as the closest government apparatus to the community.

Thinking Framework

In an organization, leadership is very central position in determining the organization's direction. The ideal leadership for every organization, especially for public organizations, is the person who is able to direct and mobilize all resources owned by the organization optimally. Several researches have examined the leadership factor in improving organization especially towards its employees (Adanri 2016; Asrori 2018; Basit and Sebastian 2017). Therefore, this study will focus on examining the leadership factor in providing motivation to improve effective services.

\section{Research Methods}

The research method is designed through research steps starting from operationalizing the variables, determining the types and sources of data, methods of collecting data or surveys, the research model, and it ended with designing data analysis and hypothesis testing. In conducting research, it needs a method, manner, or tactic as steps that must be taken by a 
researcher in solving a problem to achieve a goal. In this study, the research method used was quantitative descriptive method. By using this method, the writer intends to collect historical data and observe closely about certain aspects relating to the problem being investigated so that the investigation will obtain data that can support the preparation of research reports. The obtained data were then processed and analysed further based on the learned theory so as to obtain a description of the object, and conclusions can be drawn about the investigated problem. In this study, based on (Sugiyono 2008) stating that, for general guidelines, it can be said that if the public is below 100 people, a sample of $50 \%$ can be used; and if it is above 100 people, a sample of $15 \%$ can be used. Based on the that, the number of samples taken is $50 \%$ of 56 people (total public) which were 28 people. It is based on the calculation of $50 \% \mathrm{X}$ 56 people $=28$ people. To determine the sample that will be used in research, the writer used the Non-Probability Sampling method using the type of Purposive Sampling. In this study, the sample used was taken using this following criterion: employees becoming respondents were employees who had more than 1 year of service. The consideration is based on the reason that they are individuals having enough experience and understanding the condition of the organization. To assess the variables $\mathrm{X}$ and $\mathrm{Y}$, the analysis used was based on a percentage of each variable. This average value was obtained by adding up the total data in each variable, then divided by the number of respondents and multiplied by one hundred percent. After obtaining the average percentage of each variable, it is then compared with the criteria that the writer determines based on the lowest and the highest value from the questionnaire results.

\section{Discussion}

In the implementation of public administration services, it requires hard work and high discipline from all parties, both from the employees themselves as executors of the work and from the top management as the leadership of the organization. Therefore, the effectiveness of public administration services is created. In order to increase the effectiveness of the service, it is necessary to have encouragement that can foster the enthusiasm and passion of the employees' work by giving encouragement is called motivation. Likewise, to increase the effectiveness of public administration services at the sub-district office of Argapura, Majalengka, motivation needs to be carried out so that it can foster and increase the enthusiasm and passion of employees' work in carrying out public administration services. In the implementation of motivation carried out by the sub-district head of Argapura,

Majalengka, it is necessary to have a measuring tool, namely the principles of motivation. Based on the principles of motivation, the implementation of motivation by the sub-district head will be more directed and dynamic so that it will accelerate the increase in the effectiveness of public administration services. The principles of motivation that are applied are as follows:

- The principle of participation

- The principle of communication

- The principle of recognition

- The principle of delegated authority

- The principle of mutual attention 
Regarding to the implementation of motivation carried out by the sub-district head in an effort to improve the effectiveness of public administration services at the sub-district office of Argapura, the writer explains the results of the study as follows:

- The principle of participation, has an average value of two indicators of $62.5 \%$ which is "Good Enough".

- The principle of communication, has an average value of two indicators of $70 \%$ which is "Good Enough".

- The principle of recognition has an average value of two indicators of $52.5 \%$ which is "Poor".

- The principle of authority, has an average value of two indicators of $67.5 \%$ which is "Good Enough".

- The principle of mutual attention, has an average value of two indicators of 55\% which is "Poor"

Of the five principles, if averaged, it reaches $61.5 \%$, so that if it is connected with the measurement criteria, the data analysis will only reach the predicate "Good Enough". These results indicate the significance of the effect of leadership in improving employee performance through motivation. This is consistent with research conducted by (Khuong and Hoang 2015; Nawoseing and Roussel 2017). The results of this study found that there are still significant opportunities in implementing the principles of motivation of their employees, considering that their performance has not been fully maximized. The implementation of motivation has an effect on the effectiveness of public administration services at the subdistrict office of Argapura, Majalengka. This is supported by previous research conducted by (Habba et al. 2017; Pahi and Hamid 2015; Yusop, Mariam, and Azam 2014). The results of the research discussion on the effectiveness of public administration services can be seen as follows:

- Production, an average value of $67.5 \%$ which is "Good Enough".

- Quality, an average score of $62.5 \%$ which is "Good Enough".

- Efficiency, an average value of $60 \%$ which is "Good Enough".

- Flexibility, an average score of $52.5 \%$ which is "Poor".

- Satisfaction, an average value of $52.5 \%$ which is "Poor".

The effectiveness of public administration services at sub-district office of Argapura has not been fully implemented properly, only reaching an average value of 59\%, or based on data analysis assessment standards, the effectiveness of public administration services at subdistrict office of Argapura has achieved predicate "Good Enough". Based on the results of the implementation of motivation carried out by the sub-district head and the effectiveness of public administration services, it can be concluded that the implementation of the motivation carried out by the sub-district head, based on the implementation of principles of motivation, affects the effectiveness of public administration services. It is proven that the implementation of the principles of motivation has only reached $61.5 \%$, which is "Good Enough", and the effectiveness of public administration services has only reached $59 \%$, which is "Good Enough". Thus, the motivation implemented by the sub-district head of Argapura has not been able to affect the increase of the effectiveness of public administration services properly, so that the motivation just reaches "Enough", resulting the effectiveness of public administration services reaching "Enough" as well. 


\section{Conclusions}

The implementation of motivation by leadership has not yet fully applied the principles of motivation. It only reached $61.5 \%$, resulting a good enough predicate. Therefore, the leader should understand and implement the principles of motivation in accordance with the results of the study. The findings of subsequent studies are that the effectiveness of public administration services has only been applied to reach 59\%, resulting a good enough predicate. The implementation of motivation applied by the leadership has an effect on the efforts to increase the effectiveness of public administration services at the sub-district office of Argapura, Majalengka.

\section{References}

Adanri, Adebayo A. (2016). "Nigerian Public Administrators' Leadership Styles and Their Perceived Effectiveness." 6(9): 85-92.

Asrori, Sobikhul. (2018). "The Effect of Transformational Leadership Style on Job Satisfaction with Trust-In-Leader as Intervening Variable." Journal of Innovation in Business and Economics 02(02): 61-70.

Basit, Abdul, and Veronica Sebastian. (2017). "Impact of Leadership Style on Employee Performance (A Case Study on a Private Organization in Malaysia)." International Journal of Accounting \& Business Management 5(2): 112-30.

Edwards, George C. (1996). Organization. 8th ed. Washington D.C.: Congressional Quarterly Press.

Gibson, James L., John M. Ivancevich and James H. Donnely Jr. (2006). Organisasi: Perilaku, Struktur, Proses. (Terjemahan) Edisi Delapan. 8th ed. Jakarta: Binarupa Aksara.

Habba, Dahlan, Basri Modding, Muh Jobhaar Bima, and Jamaluddin Bijang. (2017). "The Effect of Leadership, Organisational Culture and Work Motivation on Job Satisfaction and Job Performance among Civil Servants in Maros District Technical Working Unit." IRA-International Journal of Management \& Social Sciences 07(01): 52-64.

Hadiyati, Ernani. (2014). "Service Quality and Performance of Public Sector: Study on Immigration Office in Indonesia." 6(6): 104-17.

Hasibuan, Malayu S.P. (2016). Manajemen Sumber Daya Manusia. Jakarta: Bumi Aksara.

Hersona, Sonny., Iwan Sidharta. (2017). "Motivation and Work Discipline on Employees Performance." Journal of Apalied Management (JAM) 15(3).

Hsiao, Chih-tung, and Jie-shin Lin. 2008. "A Study of Service Quality in Public Sector." 6(1): 29-37.

Khuong, Mai Ngoc, and Dang Thuy Hoang. (2015). "The Effects of Leadership Styles on Employee Motivation in Auditing Companies in Ho Chi Minh City , Vietnam." International Journal of Trade, Economics and Finance 6(4).

Naile, Idah, and Jacob M Selesho. (2014). "The Role of Leadership in Employee Motivation." Mediterranean Journal of Social Sciences MCSER Publishing, Rome-Italy 5(3): $175-82$.

Nawoseing, Daniel, and Josse Roussel. (2017). "Influence of Leadership Styles on Employees ' Performance : A Study of Turkana." International Journal of Business and Social Science 8(7): 82-98. 
Pahi, Munwar Hussain, and Kamal Ab Hamid. (2015). "How Leadership Styles Influence Commitment to Service Quality ( CSQ ): A Case Study of Hospitals of Sindh Pakistan." Mediterranean Journal of Social Sciences MCSER Publishing, Rome-Italy 6(6): 282-95.

Ramseook-munhurrun, Prabha, Soolakshna D Lukea-bhiwajee, and Perunjodi Naidoo. (2010). "Service Quality in the Public Service." 3(1): 37-50.

Siwi, Marheni Dharyadi, Siswandari, Gunarhadi. (2019). "The Correlation Leadership, Motivation, Work Climate and Highe Economic Teachers' Performance in Karanganyar Regency.” International Journal of Active Learning 4(1): 45-58.

Sondang Siagian. (2012). Teori Motivasi Dan Aplikasinya. Jakarta: Rineka Cipta.

Sugandha, Dann. (1991). Koordinasi Alat Pemersatu Gerak Administrasi. Jakarta: Intermedia.

Sugiyono. (2008). Metode Penelitian Kunatitatif Kualitatif Dan $R \& D$. Bandung: Alfabeta. Yusop, Salwa, Siti Mariam, and Mohd Azam. (2014). "An Effective Leadership Practices in Motivating Malaysian Employees: From Malaysian." ournal of Advanced Social Research 4(11): 1-16. 